\title{
Customer orientation as a driving force to build innovative networks in security business
}

\author{
K. Palomäki \\ VTT Technical Research Centre of Finland, Finland
}

\begin{abstract}
This paper describes the Finnish security business sector through the lens of market and customer orientation. Security business field has been considered as a very potential business area. Moreover, security features are playing some kind of a role in all businesses, among both traditional security and safety providers and other industries that have security only as a perspective. As the security sector and its operational environment change, companies within the business field need to be able to follow and understand the changes, and in order to be competitive, act on them. The study is based on the empirical data gathered in one-year research project. Among the participants and interviewees were persons from various associations, governmental organisations, research sector and companies, all associated with the security industry. The aim of the study is to look into on-going market trends and future customer needs within the Finnish private security sector, and to explore how the sector is prepared to answer to these new customer needs. Moreover, the study aims to find out how the customer needs could be answered better. Results point to the need for different kinds of logistical security and safety solutions, home security and safety solutions, solutions for the protection of environment and infrastructure, solutions relating to health care, and data security and protection. More generally, a need for more comprehensive security solutions was discovered. The findings suggest that in order to answer to the customer needs of the security business sector, new security networks are needed.
\end{abstract}

Keywords: security business, network, innovation, security network, customer needs.

\section{Introduction}

The growth of private security has been described as 'extraordinary and global', and for example in Europe, the total number of security personnel has more than 
doubled between 1999 and 2004-2005 (Van Steden and Sarre [1]), which describes the growing weighting of the business sector. According to Erickson [2], sector consists of guarding services, private investigation, and physical security products, such as burglar alarm systems. In Finland, the most important security products and services relate to guarding, structural security and safety products, electronic security systems, and data security products and services (Lith [3]).

Guarding and burglar alarms are good examples of offerings that are in the very core of the private security business. However, Van Steden and Sarre [1] argue that private security has become increasingly "everybody's business". In addition to companies that provide security as their core offering, security issues are playing some kind of a role in every business sector and all businesses: Security and safety can be added to any core product or service offering as a minor element, or it can be the most important feature and selling argument of the offered product or service, as it is with traditional security and safety providers (Kupi et al. [4]).

What is behind the growth and these ongoing changes within the security business sector? Van Steden and Sarre [1] argue for sociological, criminological, economic, geographical and political dynamics that explain the changes in private security. Behind these primary factors are the driving forces such as technological developments, globalisation, demands of people for protection, crime rates, fear of crime and disorder, increases in income and wealth, spatial changes, and build up of 'mass private property' and communal spaces, inadequacy of public funding, and privatisation that are all affecting the business and its opportunities [1]. In order to be competitive in this changing business, it can be claimed that for security companies it is important that they follow and understand what is going on in the operational environment and among customers.

This paper describes the Finnish security business sector from the viewpoint of market and customer orientation. The aim of the study is to look into on-going trends and future customer needs within the Finnish private security sector, and to explore how the sector is prepared to answer to these new customer needs, and moreover, how the customer needs could be answered better. This paper begins with literature review that addresses customer orientation and networking towards customers. The second section presents the research methodology. In the third section, the empirical findings of this study are introduced. Finally, conclusions and limitations are discussed.

\section{Background}

\subsection{Customer orientation}

According to Kotler and Armstrong [5], "achieving organisational goals depends on determining the needs and wants of target markets and delivering the desired satisfaction more effectively and efficiently than competitors do". In order to recognise these needs and wants, i.e. business opportunities, versatile opinions 
and different perspectives both in and outside organisation are needed (Chesbrough [6]). For a company, this so called market orientation is valuable because it emphasises continuous collection of information about customers' needs and competitors' capabilities, and using this information to create superior customer value. In addition to follow-up of customers and competitors, market orientation entails learning about the influence of technology, competition, as well as other environmental forces. (Slater and Narver [7], Matthing et al. [8]). Slater and Narver [7] argue that conception of market should be broadened to encompass all sources of relevant knowledge and ideas pertaining to customers and customer value creating capabilities, and point out that in the literature, such terms as 'market-oriented', 'market-driven', and 'customer-focused' are often understood as synonymous. Also according to Matthing et al. [8], looking beyond the familiar assumptions of a company, new directions and possibilities, and thus new innovative services can be discovered.

Companies can seek for the so called product possibilities, i.e. market gaps which could be filled with new or developed products that answer to upcoming trends and customer expectations. Trends affecting customers and users, their needs and expectations, way of use and situation are all to be studied in order to find new innovation areas and concrete product or service ideas (Cagan and Vogel [9], Kuismanen and Poskela [10]). For example, Cagan and Vogel [9] suggest studying social, economical and technical trends affecting customers in order to find various product possibilities. Information about customers and thus knowledge about business opportunities can be collected through different kinds of contacts, market research, questionnaires and interviews, in the form of customer feedback, developed from the terms that legislation and standards presume, or for example through workshops. Not only direct customers but also customers' customers and end-users have to be taken into account. Moreover, actors affecting and supporting the service as well as decision makers, specialists and the actual realisers all have to be considered. Utilising stakeholders also outside an organisation is according to the principles of open innovation. (Kuismanen and Poskela [10], Korhonen and Rajala [11], Honkala et al. [6, 12]).

When talking about market-oriented companies, it needs to be stressed that plain customer orientation is not enough but organisations need to continually collaborate and learn with customers in order to respond to their needs [8]. Therefore, companies have to create a culture, structures and processes that support continuous data gathering and learning [7].

\subsection{Networking and innovations}

Networking towards customers is a challenge, but according to many studies, recognising especially the needs and expectations of customers and developing these into concrete offerings is the key to successful innovations. Better customer understanding is needed in the whole business network in order to realise new opportunities and combinations of expertise [9-12] (Valkokari et al. [13]). Successful innovations are said to occur when companies recognise a gap between what the market needs and what is offered, and then successfully direct resources toward filling that need [7]. It can be argued that identified needs and 
expectations of customers function as the basis for innovative networks, i.e. they can be viewed as business goals that act as starting point for gathering different kind of actors and their resources together. As Kothandaraman and Wilson [14] condense "putting together a network of firms to build the set of capabilities necessary to build a market offering that delivers high value to the customer becomes a major strategic thrust of the firm".

From the innovation point of view, the contribution of other stakeholders must not be forgotten however. Many studies have pointed out that companies that have a close relationship not only with their customers but also suppliers, research institutions and competitors, are more likely to thrive with research and development, even with product and process innovations. Therefore, developing, managing and utilising different kinds of networks is in the key position when creating new innovations (Ritter and Gemünden [15], Tidd and Bessant [16]). As companies can network vertically thus focusing on suppliers and customers, and horizontally with competitors, research institutions and public governance (Möller et al. [17], Möller et al. [18]), it can be argued that when aiming to true innovations, both vertical and horizontal relationships are needed. According to Tidd and Bessant [16], interfaces of different kinds of expertise and know-hows in addition to collective efficiency, learning and risk taking are drivers for innovative networks. Also Powell et al. [19] state that innovations are created in between companies, universities, research institutions and customers, rather than within any individual actor (Powell [20]).

In summary, as the above literature illustrates, many scholars see customer orientation as important but also remind of the significance of versatile perspectives and expertise in networks. In this study, innovative networks are discussed as one form of more customer-oriented business.

\section{Methodology}

\subsection{Research philosophy}

Methodology is the general approach to studying research topics, and it describes the decisions of a researcher including philosophical commitment and the methods, i.e. specific research techniques, used in the research. This study is qualitative study for which interviews, discretionary sampling, inductive analysis of data as well as coding and interpreting transcripts are all typical features (Silverman [21], Easterby-Smith et al. [22]). In this research study, the main emphasis is on understanding meanings and making constructions. Theory is developed inductively and founded on observations, without forming hypotheses (Brewerton and Millward [23]). This study is descriptive by its nature, and it pursues to understand, describe and analyse the features of the Finnish security business field from the viewpoint of customer orientation. According to Silverman [21], in qualitative research 'authenticity' rather than reliability is often the issue. This paper describes the Finnish security business sector from the viewpoint of market and customer orientation. The study is based upon stakeholder interviews and two one-day workshops organised for different actors 
working in the business field. Like Silverman [21] describes, the aim also in this study is to gather an authentic understanding of people's experiences, and to achieve this, open-ended questions are seen to be the most effective way.

\subsection{Interviews}

The interviewees $(n=15)$ came from various backgrounds, that is from education, research institutes, public sector and companies, and presented a variety of viewpoints - corporate security, crises management, national and internal security, security and safety management, private security as well as security of areas and separate targets. With this diversified sampling, the aim was to form a rich and diversified understanding of the security business field.

The interview data was collected using semi-structured interviews. The interview guide consisted of a set of discussion themes that gave frames and topics to the discussion but allowed the interviewees to discuss the features of the security sector quite freely. The interviews were recorded, and transcriptions and memos of each interview were written. First, the collected interview data was analysed by grouping it around the themes and topics of the interview guide and also around the themes that rose from the data. Atlas.ti software was used in the beginning of the analysis to help create and assign qualitative codes, and also in later stages of the analysis when going through the whole data that had been processed according the themes of the interview guide. At this stage, the codes were created to match better with the research questions and the key findings of the literature. The main codes were innovativeness, networks and collaboration, customer orientation, customer needs of the future and potential markets, and present state and special features of security business. In this study, the analysis focuses particularly on the codes of customer orientation, and on customer needs of the future and potential markets.

\subsection{Workshops}

As the interviews looked mainly into the features of the Finnish security business field, the workshop data focused on finding out and exploring views of actors working in the security business sector on customer needs of the future. Two different workshops were arranged, and in total 18 persons took part in the first workshop and 19 in the second workshop. The participants represented education, research institutes, companies, public sector, e.g. different ministries, and other organisations. In the first workshop, the aim was to find out and describe drivers, trends, weak signals and various views affecting and acting in the security sector in Finland. In addition to group works and discussions, a computerised group support system that consisted of networked computers and software was used to gather and organise participants' comments. Trends and drivers were collected under the topics of the PESTE model, i.e. political, economical, social, technical and ecological, after which they were organised into 16 themes and furthermore prioritised. In the second workshop these prioritised trends and drivers were utilised in the customer needs matrix that was 
used as a data collection method. The matrix was constructed so that seven of the driver themes formed one axis, and nine major customer groups the other axis.

The customer needs matrix aimed to be a tool for creating ideas of the customer needs and potential new markets of the future. The participants were given a task to think up creatively various needs that the recognised current trends and drivers would generate in the most important customer groups of security and safety sector. The participants were encouraged to not to take into consideration the limitations that for example the current level of technology sets but think up the future needs as innovatively as possible. The matrix task in the workshop was taken through on a very general level but the idea behind using it was to capture how new products, services and solutions could be imagined through thinking the major trends and changes and moreover their affect on different customer groups thus also affecting emerging customer needs. This matrix is one way and a supporting tool for creating, learning and collecting knowledge about what the customers might need in the future and how their expectation can change because of the changes and trends in their environments.

\section{Results}

\subsection{Customer orientation}

Security business field was seen as very technology and product oriented, and technologies and product's functioning were said to lead also research and development activities. The interviews confirmed the view that user should be involved in the development activities as early as possible in order to meet the customer needs. However, it was argued that user or user's needs are not considered enough. Good knowledge about customer needs was considered to be important also when forming structures and finding partners to cooperate. Customers from different backgrounds may be looking for solutions for similar kinds of problems, to which technology or service provider can answer with one solution. Therefore, interviewees suggested that structures of cooperation such as networks or clusters need to be formed from the customer point of view, i.e. companies have to be customer oriented, not technology or product oriented. In other words, instead of technologies, customer needs were seen as the best starting point when forming new collaborations.

According to the interviews, customers are becoming more critical buyers than before, and also more aware of different solutions. Moreover, customers do not content with separate, disconnected solutions. Some argued that customers are not necessarily capable to assess their needs however. The buying situation was recognised to become more difficult if there are many buyers on the customer's side, and if the situation is somehow uncoordinated. Also suppliers' lack of know-how may be a constraint for business.

Nonetheless, buyers' level of know-how was considered improved because of networking and education. More and more often companies expect wellgrounded and justified purchases, and this is why critic towards and awareness of different solutions is rising higher. For example, public administration was 
considered as a critical customer that takes part in developing services by making demands and following their implementation. Still, it was argued that authorities that are a major customer group do not take part in research and development enough. Criticalness of customers forces producers and service providers to understand customers' businesses and risks better. However, though more demanding customers, auditing is still rare.

For a customer, price was seen to be a key determinant, and customers do not really take part when designing and defining the contents of a service. As the views of customer and security provider do not meet, the customer is offered a product or service that does not answer to the needs and might be wrongly priced. Security services may still be regarded as something that a company has to take into consideration just because others do so. This is why price can be left as the only determinant. Customers might also think that investing in security is reasonable only because of its effects on brand, not because of improvements in the security level. Customers abide by existing and most ordinary option, and security feature does not necessarily affect the choice. On the other hand, it was pointed out that as reliability of security products and services is crucial for their users, customers are not so eager to change the solution or provider but rely on solutions that have already been used and regarded good.

According to interviews, security providers are considering customer needs more than before, and their expertise is appreciated. The requirements of customers were expected to grow, and therefore security providers need to consider users more than before, and e.g. tailor solutions to meet their needs better. Associations were mentioned as a way to develop collaborational activities and new consortiums between different actors. Companies should have more information about markets, needs and possibilities, especially if aiming to grow in the international markets. In addition to networking possibilities, associations can also gather important information for example about the actors, price level and trends in the markets to the use of their members.

\subsection{Follow-up of operational environment and trends}

The key motivator for a customer to purchase a security product or service is the need for business operations that are undisturbed, reliable, good quality and easy. Customers do not look for security products particularly but products that are functional, and that have security as a built-in element that adds to the actual purpose of the product. One interviewee pointed out that instead of selling security with negative arguments or images of threats, companies should sell with promises, such as promise of good service and ease of use. Therefore, instead of cost factors, security products and services should be marketed as savings factor from the viewpoint of customers. Moreover, as an interviewee stated, the actors of the business field should consider security as enabling feature, not only as obligation.

A need for more comprehensive solutions and service bundles that are provided by one security provider was detected. This need is fuelled by growing costs and customers' lack of time but also by difficulties relating to using and connecting of separate solutions. Moreover, because of better level of expertise, 
customers are no longer satisfied with separate, unconnected technical solutions. In addition to more comprehensive solutions, aim is towards more versatile technologies and solutions that are integrated to existing products and systems. The servitisation trend, i.e. adding services to products, was detected also in security sector, although at the same time the proportion of technologies in solutions was expected to grow. However, instead of considering solely technological security and safety solutions, alternative perspectives are needed. Incorporating security and safety issues into e.g. planning of urban and suburban areas is a good example of this wider way of thinking.

Aging, climate change, mobilisation of people, polarisation and inequality, and social alienation are all megatrends that are expected to lead to growing demand for security and safety products and services. Because of fast flow of information and mobilisation of people, different kinds of phenomena, both negative and positive, can spread out and realise in Finland, too. Also threat of violence, radicalisation and terrorism were recognised as factors that have influence on security business. These trends have lead e.g. to approval of certain technologies, and they have had an influence on the conceptualisation of the security business sector.

Internationalisation and development of societies, e.g. tightening economic situations, have an influence on how security level is perceived. If e.g. polarisation develops further, people may feel that the society they belong to is unable to secure their living, which leads to growing demand for security products and services provided by private security sector. Also governmental changes, such as changes in the European Union level may result in increased competition for market shares and thus higher standards. Especially changes in legislation were seen to have an influence on security business.

More generally, interviewees argued that in Finland as well as in the whole Europe there is an on-going security trend, and security considerations can be seen everywhere. The trend has lead to growing demand for security products, e.g. surveillance cameras. However, it was pointed out that investing in security products and services is not only caused by insecurity of people but is also simply reasonable development towards secure and safe environment.

\subsection{Future customer needs}

In addition to the recognised need for more comprehensive solutions, interviews and workshop data pointed out many sectors where considering security could have a special role. Interviewees and workshop participants also suggested that these sectors could become new potential market areas for security business, and presented also some quite specific product or service needs. The future customer needs that came up in the workshop task can be grouped under four themes, which are logistical security and safety solutions (e.g. RFID solutions, standardisation, tracking, navigation, follow-up), solutions for home automation and home security and safety (e.g. solutions that combine both energy and security management), solutions for the protection of environment and infrastructure (e.g. preventing crimes towards environment, community planning, continuity management), and solutions relating to health care (e.g. 
nursing robots, follow-up of an employee's health in industrial plant, models for well-being at work, self diagnosing, patient security and safety).

Also the interview data gives support to these findings: Security systems and services were seen as potential to the business field of transportation and logistics. Preventing criminal activities and terrorism, follow-up and controlling of persons and goods, border crossing, free movement, and more specifically, the geographical position of Finland next to Russia all make the operational environment challenging. In addition to the aforementioned, also new kinds of weather conditions may create new customer needs. Partly relating to health care, solutions that make it possible for people to stay in their homes for as long as possible are needed, and solutions for nursing, housing and everyday life are seen as very potential in the markets. Security products such as wireless locking and surveillance solutions are expected to become more common. Interviewees also highlighted elderly people's need for more sophisticated solutions in which security and safety would be a built-it element. Also crises management and protection of critical infrastructure were considered as potential. In Finland, there could be demand for specialist services, such as consulting and training services designed for companies that operate in demanding environments. Moreover, needs for integrators and consulting targeted at coordinating collaboration, and for security portal that gathers security and safety information for the use of companies and other actors were presented. Finally, relating to security management of companies, a need for tools for example for reporting or supplychain supervision purposes was suggested. Just to mention few, some other named potential security business areas are verification solutions, security solutions for environment protection, camera surveillance systems, and wireless products in locking and surveillance system solutions. Also data security, e.g. cryptography, and functionality of systems in homes and companies were seen to be very important.

More generally, though the business environment changes all the time, elements of security business sector were expected to remain the same. Development of security sector is conditional on development of other business sectors, and on business sectors of its customers. Therefore, substantial is, what will be adapted from outside the business sector. In summary, the interview and workshop data illustrated the following major future customer needs: the need for different kinds of logistical security and safety solutions, home security and safety solutions, solutions for the protection of environment and infrastructure, solutions relating to health care, and data security and protection.

\section{Conclusions}

The results revealed that one of the major issues among customers of the security business sector is the need for more comprehensive security solutions. In order to be able to develop these, different fields of know-how, and different products and services need to be brought together and connected to form one solution, a "service bundle", which then can be offered to the customer by one provider. Solutions provider has been described as a resolver of customer's specific 
business, rather than technological need (Shepherd and Ahmed [24]). As companies are focusing more and more on their ever narrower core competencies and outsourcing other functions, such a comprehensive need cannot be answered by one company. Therefore, it can be argued that in order to answer to the customer needs of the security business sector, networks that offer more comprehensive solutions are needed.

Literature has described security business not to be formed solely of private or public sectors' actors but of complex networks of different kinds of security actors (Abrahamsen and Williams [25]). Security networks have also been described as a group of institutional, organisational, communal or individual actors or hubs that are directly or indirectly connected to each other, and that act to authorize or/and to offer security (Shearing and Wood 2000, according to Dupont [26]). Dupont [26] states that typical for a security network is the discrepancy and diversity of hubs that can be big governmental actors, international companies or smaller local organisations. As the scarce security network literature, so has this study recognised the versatility of actors of security networks.

Gathering of different kinds of expertise together to create more comprehensive and multifaceted offerings to customers is one of the many drivers that lead to collaboration and more networked ways of working. Thus, motives for collaboration are one major element driving networking of companies. To describe this better, in case of strategic interfirm technology cooperation, motives can be organised into three groups that are 1) motives related to basic and applied research and some general characteristics of technological development, 2) motives related to concrete innovation processes, and 3) motives related to market access and search for opportunities. Among others, factors behind these motives include more complicated technologies, sharing research and development costs as well as knowledge and technologies, and need for monitoring of environmental changes and opportunities with partners (Hagedoorn [27]). Difficulty of separate, unconnected technical solutions, changes in markets and operational environment as well as changes among customers and their needs can be recognised as driving forces of networking also in this study. Moreover, increasingly more sophisticated customers with improved understanding of the technology available have lead to greater market "pull", i.e. demands of customers set to the offered solution [24].

Therefore, as a conclusion, it can be argued that only through networking businesses can adapt to and be competitive in the changing operational environment, and answer to the needs of customers with more comprehensive and innovative solutions. Creating security networks that unite various actors, expertise and knowledge, e.g. about trends, in a way that answers to changes within the business sector and to the needs among customers is needed in the security business sector. Thus, the research suggests ways how security service managers could consider the needs and changes taking place among customer better.

As with any empirical study, this one also has some limitations. First, this study focused on the Finnish security business sector and on a specific area of 
service, and therefore the results cannot be generalised directly to another markets or sectors. Second, in addition to workshops, this study used in-depth interviews and caution is required also in generalising the findings beyond the sample.

\section{References}

[1] Van Steden, R. \& Sarre, R., The tragic quality of contract guards: A discussion of the reach and theory of private security in the world today. The Journal of Criminal Justice Research, 1(1), pp. 1-19, 2010.

[2] Erickson, B.H., Good networks and good jobs: The value of social capital to employers and employees. Social capital: Theory and Research, eds. N. Lin, K. Cook \& R.S. Burt, Aldine de Gruyter: New York, pp. 127-158, 2001.

[3] Lith, P., Turvallisuusalan yritysten suhdanne- ja toimialaraportti 2009, Finnsecurity ry: Helsinki, 2009.

[4] Kupi, E., Kortelainen, H., Lanne, M., Palomäki, K., Murtonen, M., Toivonen, S., Heikkilä, A.-M., Uusitalo, T., Wuoristo, T., Rajala, A. \& Multanen, A., Turvallisuusalan liiketoiminnan kasvualueet ja mahdollisuudet Suomessa, VTT: Helsinki, 2010.

[5] Kotler, P. \& Armstrong, G., Marketing. An introduction (4 ${ }^{\text {th }}$ edition), Prentice Hall: NJ, 1997.

[6] Chesbrough, H.W., Open Innovation. The New Imperative for Creating and Profiting from Technology, Harvard Business School Press: Boston, Massachusetts, 2003.

[7] Slater, S.F. \& Narver, J.C., Market orientation and the learning organization. Journal of Marketing, 59(3), pp. 63-74, 1995.

[8] Matthing, J., Sandèn, B. \& Edvardsson, B., New service development: learning from and with customers. International Journal of Service Industry Management, 15(5), pp. 479-498, 2004.

[9] Cagan, J. \& Vogel, C.M, Kehitä kärkituote - ideasta innovaatioksi, Talentum, Tekniikan Akateemiset ja Insinööriliitto: Helsinki, 2003.

[10] Kuismanen, O. \& Poskela, J., Kilpailuetua systemaattisesta mahdollisuuksien tunnistamisesta, Projektitoiminta 1/2008, Projektiyhdistys ry: Espoo, 2008. pp. 48-52.

[11] Korhonen, H. \& Rajala, A., Verkostoituminen asiakassuuntaan - kohti globaalia palvelutarjontaa. Verkostot liiketoiminnan kehittämisessä, eds. K. Valkokari, R. Hyötyläinen, H.I. Kulmala, P. Malinen, K. Möller \& J. Vesalainen, VTT and WSOY: Helsinki, pp. 193-214, 2009.

[12] Honkala, S., Hämäläinen, M., Koisaari, T., Reinikainen, M., Sipilä, P. \& Vanhamaa, M., Tuotekehityksen ABC-kirjanen, TKK Koneensuunnittelu: Helsinki, 2006.

[13] Valkokari, K., Valjakka, T. \& Korhonen, H. Verkostot liiketoiminnan uudistamisessa. Verkostot liiketoiminnan kehittämisessä, eds. K. Valkokari, R. Hyötyläinen, H.I. Kulmala, P. Malinen, K. Möller \& J. Vesalainen, VTT and WSOY: Helsinki, pp. 115-131, 2009. 
[14] Kothandaraman, P. \& Wilson, D.T., The future of competition. Valuecreating networks. Industrial Marketing Management, 30, pp. 379-389, 2001.

[15] Ritter, T. \& Gemünden, H.G., Network competence: Its impact on innovation success and its antecedents. Journal of Business Research, 56, pp. 745-755, 2003.

[16] Tidd, J. \& Bessant, J., Managing innovation - Integrating technological, market and organizational change $\left(4^{\text {th }} \mathrm{ed}\right)$, John Wiley \& Sons Ltd: England, 2009.

[17] Möller, K., Rajala, A. \& Svahn, S., Strategic business nets - their type and management. Journal of Business Research, 58, pp. 1274-1284, 2005.

[18] Möller, K., Rajala, A. \& Svahn, S., Tulevaisuutena liiketoimintaverkot Johtaminen ja arvonluonti. Teknologiateollisuuden julkaisuja nro 11/2004 (2nd ed.), Teknologiateollisuus ry: Helsinki, 2006.

[19] Powell, W.W., Koput, K.W. \& Smith-Doerr, L, Interorganizational collaboration and the locus of innovation: Networks of learning in biotechnology. Administrative Science Quarterly, 41(1), pp. 116-145, 1996.

[20] Powell, W.W., Neither market nor hierarchy: Network forms of organization. Research in Organizational Behavior, 12, pp. 295-336, 1990.

[21] Silverman, D., Interpreting qualitative data. Methods for analysing talk, text and interaction ( $2^{\text {nd }}$ edition), SAGE Publications: London, Thousand Oaks and New Delhi, 2001.

[22] Easterby-Smith, M., Thorpe, R. \& Lowe, A., Management research. An introduction ( $2^{\text {nd }}$ edition), SAGE Publications: London, Thousand Oaks and New Delhi, 2002.

[23] Brewerton, P. \& Millward, L., Organizational research methods - A guide for students and researchers, SAGE Publications: London, 2001.

[24] Shepherd, C. \& Ahmed, P.K., From product innovation to solutions innovation: A new paradigm for competitive advantage. European Journal of Innovation Management, 3(2), pp. 100-106, 2000.

[25] Abrahamsen, R. \& Williams, M.C, Security sector reform: Bringing the private in. Conflict, Security \& Development, 6(1), pp. 1-23, 2006.

[26] Dupont, B., Delivering security through networks: Surveying the relational landscape of security managers in an urban setting. Crime, Law \& Social Change, 45, pp. 165-184, 2006.

[27] Hagedoorn, J., Understanding the rationale of strategic technology partnering: interorganizational modes of cooperation and sectoral differences. Strategic Management Journal, 14(5), pp. 371-385, 1993. 